\title{
Bytes and Pieces: Fragmented Copies, Licensing, and Fair Use in a Digital World
}

\author{
Jonathan Dowell $\dagger$
}

Over the past two decades, an economic interpretation of copyright law's fair-use doctrine has taken hold in court decisions and academic discourse. This interpretation posits that fair use exists in large part to counteract economic imperfections that prevent smooth functioning of the copyright marketplace. Recently, commentators focusing on this type of analysis have predicted a drastically reduced future for fair use in digital media such as the Internet. The Clinton Administration's task force on digital issues, adopting these commentators' logic, has suggested that fair use may be unnecessary when an owner can license uses. This conclusion rests on the idea that if an owner can license the use, then the market is free of imperfections, and thus fair use is unnecessary. The author agrees that the Internet will markedly reduce many types of market imperfections. The Internet grants owners the ability to reach most users at very little cost. However, the author argues that important sources of market imperfection will continue to implicate the core values that animate fair-use policy. At base, the copyright framework must always serve to maximize the public benefit from expressive works. In the face of lingering bargaining costs, externalities, or antidissemination motives, the new medium does nothing to ensure that the parties to a given bargain will act with the public's best interest in mind. The author focuses on one type of copying activity central to everyday use of the Internet: fragmented literal copying of very small chunks of content. The author concludes that, notwithstanding copyright owners' ostensible ability to license these uses cheaply, fair use remains an

Copyright $\odot 1998$ California Law Review, Inc.

$\dagger$ A.B., 1992, Columbia University; J.D., 1998, University of Califomia at Berkeley School of Law (Boalt Hall). I would like to thank Tristin Green, Fumi Knox, Sherri Sokeland, Doni Gewirtzman, and all of the editors and members of the California Law Review for their hard work and valuable feedback. Additional thanks go to Professor Pamela Samuelson for help with topic selection and initial guidance. Finally, I want to commend John Stone and Nick Khadder for putting up with endless discussion of fair use technicalia and for providing helpful suggestions. Of course, any errors remain my own. 
essential tool to allow fragmented uses that will further copyright's major policy goals.

\section{INTRODUCTION}

About the time I started writing this Comment, my cousin Irene sent me an e-mail asking me to comment on the following situation: ${ }^{1}$ Irene, a school teacher, was home late one night preparing a lesson for her sixth-grade English class. She decided to log on to the Internet to see if she could find any information on the early twentieth-century American authors her class was studying. She came across a magazine article that chronicled the life of Langston Hughes. Along with biographical information, the article included several excerpts from Hughes' writing. Irene thought the material would help her students appreciate the flavor of Hughes' life and work. Accordingly, she selected a few bits of the article that would be particularly useful for classroom presentation. She chose the article's two-sentence summary of Hughes' literary style and a few lines from each of two representative poems. The magazine's home page indicated that anyone who wanted to download a copy of any article should click on a certain box. The user must agree to pay five dollars per copy, or three dollars for any part thereof. Irene wanted to know if she was violating the copyright laws by printing out the small parts of the article without paying the fee.

Irene does not deny copying some expressive content. Nonetheless, most would agree that, at least several years ago, she was a prime candidate for a fair-use justification under copyright law. ${ }^{2}$ If she qualified for a fair use, Irene could copy and use the quotes for free regardless of infringement of the author's copyright. However, today, due to recent digital advances and the Internet, Irene's ability to rely on the fair-use doctrine is much less clear.

The Internet provides members of the general public an easy way to access copyrighted works and to make fragmented copies ${ }^{3}$ of sinall parts of those works from their own desks. At the same time, it provides content owners with mechanisms to monitor and to require payment for these uses (i.e., licensing). This streamlined capability for copying and licensing has created a substantial potential surplus: although any additional copy will cost the parties practically nothing to produce,

1. The names and facts have been modified slightly to protect the people involved. The actual incident did not involve Langston Hughes or Hughes' publisher.

2. At the risk of oversimplification, the copyright system generally grants this justification to socially valuable uses and to users who might not be able to pay for the use.

3. Sometimes commentators will refer to this type of activity as de minimis copying. However, the term de minimis confuses the issue, because some courts use the term as a description, meaning a very small amount, while others use it as a conclusion, that is, copying is de minimis only if the content taken is too little to constitute infringement. 
presumably the copy still has the same beneficial value to the end-users. To the extent publishers can maintain the pricing structure from the print world, they will achieve a much higher profit margin in this new market. Conversely, users who are able to pirate copies at will can absorb the financial benefit from the new medium. With this valuable surplus at stake, content users and copyright owners have each pressed legal and policy positions that would help secure the benefit for their own group. ${ }^{4}$

In the Clinton Administration's proposal for a national policy on copyright in digital media, the Information Infrastructure Task Force's White Paper ${ }^{5}$ seems to have sided with the copyright owners. ${ }^{6}$ Although it does not take a firm position on the future of fair use, the White Paper endorses a more limited scope for the fair-use doctrine in cases in which digital technology allows owners to license the use. ${ }^{7}$ Other copyright

4. For a discussion of the various arguments pressed by copyright pessimists (corresponding loosely to the group I refer to as users) and copyright optimists (owners), see PaUL GoldsteIN, COPYRIGHT's HighWAY 15-26 (1994).

5. Working Group on INTEllectual Property Rights, Information Infrastructure TASK Force, INTEllectual Property aNd THE National INFORMation INFrastructure 1 (1995) [hereinafter White Paper]. President Clinton formed this task force "to articulate and implement the Administration's vision for the National Information Infrastructure (NII)." Id. at 1. Ronald Brown and Bruce Lehman originally chaired the group, which also included other "high-level representatives of the Federal agencies that play a role in advancing the development and application of information technologies." Id.

6. Even though the Task Force released the White Paper in 1995, the paper remains the most complete and authoritative pronouncement on the federal government's attempts to solve the problems at issue in this Comment. Several bills have been introduced into Congress that address digital copyright issues. At the time of writing, none of these bills have been enacted into law. While the bills would not affect dramatically the tension between licensing and fair use at issue in this Comment, they may signal Congress' willingness to take a more nuanced and balanced view of user's rights vis-à-vis copyright owners. The On-line Copyright Infringement Liability Limitation Act seeks primarily to limit the liability of Internet Service Providers and Bulletin Board Operators for their customers'. See H.R. 3209 (introduced February I2, 1998); H.R. 2180 (This similar bill, entitled the On-Line Copyright Liabihty Limitation Act, was originally introduced July 17, 1997). The Digital Copyright Clarification and Technology Education Act of 1997 (introduced in the Senate) and the similar Digital Era Copyright Enhancement Act (introduced in the House) address end users more directly. See S.1146; H.R. 3048. The bills would add language to the Copyright Act to state explicitly that fair use can apply to digital uses. H.R. 3048, \& 2; S.1146, \& 202. This provision would simply confirm the assumption on which the White Paper and most other analysts have rested their analyses. One other provision in these bills might subtly affect the issues addressed in this Comment: the bills would provide that "no independent weight shall be afforded to" either the manner by which the owner distributed the original work or the fact that an owner used a technological protection device. See H.R. 3048, $\S 2 ;$ S. $1146, \S 202$. Again, these two provisions would essentially confirm that fair use is not subject to special rules in the digital arena. Nonetheless, such a Congressional pronouncement would help to keep in check those courts that might otherwise find that an owner can escape the fairuse rule merely by protective measures.

7. As Professor Samuelson has explained, "The white paper attempts to eliminate fair-use rights by interpreting existing law as though fair use has no application when a use can be licensed ...." Pamela Samuelson, The Copyright Grab, WIRED, Jan. 1996, at 134, 136; see also Charles R. McManis, Taking Trips on the Information Superhighway: International Intellectual Property Protection and Emerging Computer Technology, 4I VILL. Lo Rev. 207, 268 (1996) ("[A]ll 
scholars have reached conclusions that support the White Paper's basic interpretation of fair-use policy. ${ }^{8}$

The White Paper view rests on an economic analysis of the copyright arena. Two basic premises underlie its conclusion. The first premise, often called the market-failure paradigm, posits that the fair-use doctrine is a response to economic inefficiency in the copyright market and that it primarily serves to allow uses only when market failures will otherwise prevent beneficial uses from going forward.' The second premise, an interpretation of the market-failure paradigm, posits that a fully developed digital licensing market will eliminate market failure and render fair use unnecessary. ${ }^{10}$ Thus far, proponents of fair use have largely attacked the first premise, arguing that economic efficiency is not necessarily central to the fair-use question. These proponents posit that fair use rests fundamentally on other policy concerns, such as free speech. ${ }^{11}$ Although there may be merit in these arguments, for the

that the White Paper rejects is an immediate legislative repeal of the fair use doctrine as it applies to the [National Information Infrastructure] environment; it does not necessarily oppose, and even hints that it might favor, judicial determinations reducing the application and scope of the fair use doctrine in cyberspace."). The White Paper further points to the many commentators who posit that "because it may now be technically feasible to 'meter' each use of a copyrighted work, and to charge a user a fee for the use, the concept of fair use has no place in the [digital] environment." White Paper, supra note 5 , at 17 .

8. See, e.g., Goldstein, supra note 4, at 224, 236 ("As [transaction] costs dissolve, so, too, should the perceived need for safety valves such as fair use. Indeed, the economic logic of the eelestial jukebox, when superimposed on the text of the Copyright Act, might produce a law that contains no exemptions from liability at all.... [T] he best prescription for connecting authors to their audiences is to extend rights into every comer where consumers derive value from literary and artistic works."). Id. at 236. Professor Merges has suggested that, in general, we should explore the pessibility of allowing a workable market to develop before allowing fair use: "[W]hy not fully enforce the rights and see whether the market follows? At the very least, we should grant the firms and individuals in the field an opportunity to explore the creation of a market mechanism." Robert P. Merges, The End of Friction? Property Rights and Contract in the "Newtonian" World of On-line Commerce, 12 BerkeLEY TECH. LJ. 115, 131 (1997). Both Goldstein and Merges see some future for fair use in a digital environment, although this future is of significantly reduced scope and individual instances rest on specific individual peliey justifications. See infra note 138 and aceompanying text.

9. See Wendy J. Gordon, Fair Use as Market Failure: A Structural and Economic Analysis of the Betamax Case and Its Predecessors, 82 CoLUM. L. REv. 1600 (1982). In this article, Professor Gordon first applied a market failure analysis to the fair use doctrine. The article has provided the basis for a significant body of scholarship and case law since 1982.

10. See GoldsTEIN, supra note 4, at 223-24 (discussing how the digital market can produce such efficiencies for fragmented copies).

11. See e.g., Samuelson, supra note 7, at $\mathbf{1 3 8}$ ("The notion that fair-use rights apply only when no licensing market exists is neither historically accurate nor good public poliey. It ignores some important free speech and related publie interest functions of fair use" that the Supreme Court has recognized on numerous occasions); see also Jessica Litman, Reforming Information Law in Copyright's Image, 22 DAYTon L. REv. 587 (1997). Professor Litman makes a similar, yet fartherreaching argument: "[W] the digital environment], copyright doctrine is ill-adapted to accommodate many of the important interests that inform our information policy. First Amendment, privacy, and distributional issues that copyright has treated only glancingly are central to any information policy." Id. at 590. 
purposes of this Comment, I will develop my thesis to be consistent with the premise that fair use is a response that helps to counteract economic inefficiency under the market-failure paradigm. ${ }^{12}$ However, I wish to show that the second premise above is unsound and that the marketfailure paradigm itself will not inexorably lead to the conclusion the White Paper reaches. Emerging licensing markets for fragmented copies will not necessarily increase efficiency in the copyright market in all cases and may sometimes endanger that very goal.

Part I of this Comment briefly touches on the importance of fragmented literal copying to our daily lives. It then looks at whether free use of these copies upsets copyright policy objectives. The first-order goal of the copyright system is to maximize societal exposure to expressive works. With this outcome in mind, the copyright system in the United States pursues two intermediate objectives: providing authors with incentives to create new works and maximizing public access to those works. Even though free uses of fragments undercut the potential incentives to authors, courts have long allowed such uses in the print world.

Part II explores the insights the market-failure paradigm can provide on this issue. The part gives a basic explanation of the conceptual framework and shows how the paradigm nicely justifies fair-use treatment for fragmented copying in the print world. It then examines the effect of new technologies on the analysis. The Internet facilitates licensing markets and makes it possible for users to pay copyright owners for fragmentary uses, whereas in the past such payment would have

12. Of course, there are many ways to think about fair use and many sets of terminology to explain its existence. A given reader might find that one or another of these paradigms resonates more with the way she prefers to think about copyright policy. See, e.g., Stephen Breyer, The Uneasy Case for Copyright: A Study of Copyright in Books, Photocopying, and Computer Programs, 84 HaRv. L. Rev. 281 (1970) (using a slightly different type of market argument, [then Professor] Breyer argues that the copyright monopoly should extend just far enough to pay content creators enough to continue to create, and no further, with the consequence of allowing as a fair use any use that would fall short of driving the creator out of the business); Pierre N. Leval, Toward a Fair Use Standard, 103 HaRv. L Rev. 1105 (1990) (focusing on the push for increased access and using decidedly less market-based terminology to explain the transformative benefits of certain uses, which are discussed infra Part III.B); Neil Weinstock Netanel, Copyright and a Democratic Civil Society, 106 YALE LJ. $283,288,324-36$ (1996) (analyzing copyright law and policy in terms of its democracy-enhancing function: "[C]opyright is in essence a state measure that uses market institutions to enhance the democratic character of civil society").

Other commentators disagree with the current copyright framework in a more fundamental way. See, e.g., L. Ray Patterson, Free Speech, Copyright, and Fair Use, 40 Vand. L. Rev. 1 (1987). Professor Patterson examines the historical roots of copyrights and fair use. He argues that fair use arose only as a means of protecting certain infringing uses by business competitors. See $i d$. at 36-40. He posits that application of fair use to ordinary consumers is wrong because those uses should not constitute infringement in the first place: "[T] hat an individual consumer's ordinary use, as by copying it, constitutes infringement is not just nonsense, it is dangerous nonsense that is wholly contrary to the constitutional purposes of copyright." Id. at 46. 
been impracticable. This effect provides the basis for the Task Force's conclusion that even fragmented copying may not merit fair use in the digital environment.

Part III argues that the assumption that any licensing market will be free of market failure is unwarranted. At least three specific types of imperfection ${ }^{13}$ will lead to instances of intractable market failure in the digital market. First, a type of bargaining cost will persist in the market for fragments. Because any two users' chosen fragments will be qualitatively and quantitatively different, it will be exceptionally hard to price those transfers efficiently. Second, fragmented uses often create externalities that generate benefits for society but that the user may be unable to capture. Finally, anti-dissemination motives, ${ }^{14}$ in the form of copyright owners trying to prevent the public from having certain kinds of access to their works, may lead to market failure.

Finally, I conclude that the Task Force and other policy makers should not adopt rules desigued to allow copyright owners to set up markets for fragmented copies without adequate user protection. Further, courts should not deny fair-use protection simply because a licensing market exists. Absent appropriate interference, digital licensing markets will force certain types of users to abandon the market. Unfortunately, these may be the very users copyright policy should most encourage.

\section{I}

\section{Fragmented Copying and the Copyright Framework}

Individuals routinely engage in fragmented copying in their academic, professional, and personal activities. For instance, throughout this Comment, I have copied from various law review articles and other works subject to copyright. Although I have identified all my sources, I have not sought permission from any of the authors or journals. Almost any author of a research paper, from a fourth-grade book report to a dissertation, follows the same practice. Further, at their jobs, people often prepare presentations that incorporate a chart or a useful quote someone else originally created. In these ways, as well as countless others, it is simply a part of one's daily life to copy protected works without paying. However, while this practice is socially accepted, it constitutes prima facie violation of our copyright laws.

13. Because various people use the term transaction costs in slightly different ways, 1 will refer, to the extent possible, to the particular type of cost or failure that is evident in a given instance. Compare R. H. Coase, The Problem of Social Cost, 3 J.L. \& Econ. 1, 15-19 (1960) (using transaction cost apparently to refer to any type of imperfection that leads to a market failure) with Gordon, supra note 9, at 1627-30 (evaluating costs to which I refer as tracing or bargaining costs as transaction costs, while treating other market failures, such as externality generation, as separate issues).

14. See Gordon, supra note 9 , at $1632-35$, for a discussion of this type of failure. 


\section{A. Ownership Interests vs. Public Access}

The Copyright Act of 1976 protects "original works of authorship fixed in any tangible medium of expression."15 Section 106 of the Act grants content owners certain exclusive rights over the expressive content. As a general matter, one may not make a copy of any part of that content without the owner's permission. ${ }^{16}$ Consequently, each portion of a work, which portion contains any expressive content, qualifies for protection. It would seem, then, that the fragmented copying activity described above presents a clear violation of the copyright laws.

However, owner control is not the only, or even the primary, goal of the Copyright Act. Rather, the ultimate goal is to increase the body of public interaction with the arts. This goal is fixed by the Constitution's charge to Congress "to promote the Progress of [the] ... arts."17 The Supreme Court has explained, "The limited scope of the copyright holder's statutory monopoly ... reflects a balance of competing claims upon the public interest: Creative work is to be encouraged and rewarded, but private motivation must ultimately serve the course of promoting broad public availability of literature, music, and the other arts." 18

Copyright law generally uses two tools to further this goal. First, with an eye to increasing the body of creative works, it creates incentives for authors to produce by giving them control over their works. ${ }^{19}$ Second, to allow the public to benefit from the increased body of works,

15. 17 U.S.C. § 102 (1994).

16. See 17 U.S.C. \& 106(1) (1994). Specifically, the content-owner has control over reproduction, preparation of derivative works, distribution, performance and display of the copyrighted work. See id. § 106(1)-(6).

17. U.S. Const. art. I, § 8, cl. 8.

18. Twentieth Century Music Corp. v. Aiken, 422 U.S. 151, I56 (1975); see also Pamela Samuelson, Fair Use for Computer Programs and Other Copyrightable Works in Digital Form: The Implications of Sony, Galoob and Sega, 1 J. INTELL. Prop. L. 49, 57 (1993) ("In the American tradition, the ultimate purpose of copyright is not the maximization of financial rewards to copyright owners..., but fostering the creation and dissemination of literary and artistic works in order to enhance the public's access to knowledge."). By comparison, Professor Gordon writes that copyright creates "ownership rights in intellectual property, with the primary goal of generating monetary incentives for the production of creative works, thereby 'promot[ing]the Progress of Science and the useful Arts."' Gordon, supra note 9, at 16I0. The shift im emphasis between these two formulations may seem subtle, but it can have substantial consequences.

19. Commentators have pointed out that there is an additional secondary benefit to owner control. By selking the works, authors and publishers gain valuable feedback about consumer preferences they can then use to make rational decisions about what to create in the future. See, e.g., GoldsTEIN, supra note 4, at 178-79 (describing Harold Demsetz's argument that failure to extend copyright protection in each possible instance "would deprive producers of the signals of consumer preference that trigger and direct their investments"). Professor Goldstein argues that this rationale leads us to the conclusion that "copyright should extend into every comer of economic value where the cost of negotiating a license is not insurmountably high." Id. at 179; see also id. at 229-30 (discussing how the coming global digital market can enhance such feedback mechanisms). 
copyright law, it strives to maximize the public's access to those same works.

Much of the development of U.S. copyright doctrine has centered on the attempt to resolve the tension between these two competing interests. ${ }^{20}$ The tension is manifest in several aspects of the copyright framework. ${ }^{21}$ Section 106 gives authors control over their works, while Sections 107 through 120 preserve the public's access rights. The tension is central to the definition of copyrightable subject matter, ${ }^{22}$ the idea/expression dichotomy, ${ }^{23}$ and the first-sale doctrine $;{ }^{24}$ it dictates the limited term of rights, ${ }^{25}$ and it led to the system of formalities that existed for most of the last two centuries. ${ }^{26}$ Most importantly for this

20. See, e.g., Glynn S. Lunney, Jr., Reexamining Copyright's Incentives-Access Paradigm, 49 VAND. L. REv. 483, 485 (1996) ("ID]efining copyright's proper scope has become a matter of balancing the benefits of broader protection, in the form of increased incentive to produce such works, against its costs, in the form of lost access to such works."); H.R. REP. No. 60-2222 (1909) ("In enacting a copyright law Congress must consider ... two questions: First, how much will the legislation stimulate the producer and so benefit the public; and second, how much will the monopoly granted be detrimental to the public?").

21. Congress has reaffirmed the importanco of these two goals in contexts outside the copyright statutes as well. For instance, the National Foundation on the Arts and the Humanities Act, which establishes the National Endowment for the Arts, includes a section on the Act's purpose that points to the importance of both goals. One subsection states the importance of access: "Democracy demands wisdom and vision in its citizens. It must therefore foster and support a form of education, and access to the arts and the humanities, designed to make people of all backgrounds and wherever located masters of their technology and not its unthinking servants." 20 U.S.C. $\$ 951(4)$ (1994). A separate subsection points to the importance of incentives for creation: "While no government can call a great artist or scholar into existence, it is necessary ... to help create and sustain ... the material conditions facilitating the release of this creative talent." 20 U.S.C. $\S 951$ (7) (1994).

22. Copyright protection "subsists in original works of authorship fixed in any tangible medium of expression, ... from which they can be perceived, reproduced or otherwise communicated ...." 17 U.S.C. $\$ 102$ (1994). Consequently, a content creator will receive protection only when the work is such that the public potentially can learn from, copy, and otherwise use that work.

23. See Baker v. Selden, 101 U.S. 99 (1879). The Copyright Act does not protect pure ideas (the focal point of patent law) or facts (always public domain). Rather, it protects the particular way someone chooses to express a given idea. The framework consequently leaves open the possibility that someone else can also express the idea in a different way.

24. See 17 U.S.C. \& 109(a) (1994). A copyright owner can control the first sale of a copyrighted work, but the owner does not control future sales of that particular chattel. The buyer can pass the copy along without restriction. For instance, one can resell a copy of a paperback novel without paying royalties to the author.

25. The Constitution expressly provides that the term of copyright should be limited. Accordingly, 17 U.S.C. $\$ 302$ (1994) limits the term of copyright protection to the life of the author plus 50 years. In the case of works for hire, anonymous, or pseudonymous works, the term is 75 years from first publication or 100 years from creation, whichever is shorter. After the term expires, the public has full access to use and copy these works freely. The term is ineant to be long enough to induce creation, while short enough not to hinder unduly public access.

26. For instance, the 1909 Act required publication, notice, registration and dcposit of copies with the Library of Congress. Again, an author could not gain protection unless the public was guaranteed certain access to the work. Furthermore, strict enforcement of these rules meant that more works would fall imto the public domain. Even today, there are siguificant benefits to registering a work. See, e.g., 17 U.S.C. § 411 (1994) (requiring registration prior to initiation of infringement 
Comment, the tension between creator control and public access provides much of the justification for the fair-use doctrine.

\section{B. The Fair-Use Doctrine}

Throughout fair use doctrinal development, courts have tended to focus on one or the other of the two goals in discerning the boundaries of the doctrine. Fair use originated with Justice Story's decision in Folsom v. Marsh. ${ }^{27}$ Choosing to emphasize the limited scope of the new doctrine, Justice Story focused on incentives to the creator. He acknowledged that quotation is often permissible as part of a review or in the context of a biography. However, "[i]f so much is taken, that the value of the original is sensibly diminished, or the labors of the original author are substantially to an injurious extent appropriated by another" the use is not fair. ${ }^{28}$ Other courts have focused on the public-access rationale in order to expand application of the fair-use doctrine. For instance, the Second Circuit has stated that the question must initially turn on "the nature of the materials, e.g., whether their distribution would serve the public interest in the free dissemination of information."${ }^{.29}$

Furthermore, the specific elements of Section 107 of the Copyright Act, which governs fair use, play out this dual interest. ${ }^{30}$ First, the Section lists several purposes for which fair use of copyrighted materials might be appropriate: "criticism, comment, news reporting, teaching...., scholarship, or research." ${ }^{\text {13 }}$ Next, the Section hists four factors to consider in any particular case:

(1) the purpose and character of the use, including whether such use is of a commercial nature or is for nonprofit educational purposes;

(2) the nature of the copyrighted work;

(3) the amount and substantiality of the portion used in relation to the copyrighted work as a whole; and

suit); 17 U.S.C. $\S 412$ (1994) (disallowing statutory damages and attomey's fees unless work is registered prior to infringement).

27. 9 F. Cas. 342 (D. Mass. 1841) (No. 4901). See L. Ray Patterson, Understanding Fair Use, 55 Law \& Contemp. Probs. 249 (1992) (explaining that Justice Story first enunciated a fair-use principle in order to reject and supplant the then-existing "abridgment" doctrine). Prior to Folsom. courts had "held that it was not an infringement of the copyright for another author to abridge a copyrighted book, because in doing so the seeond author produced a new book." Id. at 255-56.

28. Folsom, 9 F. Cas. at 348.

29. Rosemont Enterprises, Inc. v. Random House, Inc., 366 F.2d 303, 307 (2d Cir. 1966).

30. See H.R. REP. No. 94-1476 (1976) ("The bill endorses the purpose and general scope of the judicial doctrine of fair use, but there is no disposition to freeze the doctrine in the statute, especially during a period of rapid technological change.").

31. 17 U.S.C. $\$ 107$ (1994). This is not an exhaustive list, but indicates some uses that Congress believes are likely to advance the public's interest in dissemination of information. See H.R. REP. No. 94-1476 (1976). 
(4) the effect of the use upon the potential market for or value of the copyrighted work. ${ }^{32}$

While necessarily informed by other considerations, the elements of Section 107 roughly present the two interests laid out above. ${ }^{33}$ The list of appropriate uses, along with the first and second factors, direct the observer to consider the interest in preserving public access to certain kinds of intellectual property. Meanwhile, the second, third, and fourth factors point to the importance of maintaining the creator's control over the work and ensuring that the incentive structure remains intact.

Weighing these two goals in the context of fragmented copying, courts have tended to favor the user's rights. Whether they find a particular use de minimis, ${ }^{34}$ fair use, ${ }^{35}$ or both, ${ }^{36}$ courts have generally allowed users to make fragmented copies of print content without paying the owner.

32. 17 U.S.C. \$ 107 (1994).

33. See Gordon, supra note 9, at 1604 ("[T]he factors do implicitly direct courts to identify both the social need for the use and the possible impact on the author's economic expectations," although the ambiguity of the statutory formulation tends to "obscure the underlying issues and make consistency and predictability difficult to achieve.").

34. See, e.g., Werlin v. Reader's Digest Ass'n, lnc., 528 F. Supp. 451,464 (S.D.N.Y. 1981) (finding the copying of two separate lines from an article "to be so fragmented as to be de minimis"); see also White Paper, supra note 5, at $65 \mathrm{n} .203$ ("When copying is ... of such a small amount as to be de minimis, then there is no infringement liability."). The reader should note that courts will sometimes use de minimis to describe a slightly different situation. Instead of taking only a de minimis amount of expression, the user may take a substantial amount, yet the particular infringement is so insignificant as to cause no noticeable injury. See 4 Melville B. NimMER, NmMer on Copyright (1997) $\S 8.01[\mathrm{G}]$. For instance, a court might find that the copy made of a work when a user's computer displays it on the monitor is so transitory as to be de minimis.

35. See, e.g., Elsmere Music, Inc. v. NBC, 482 F. Supp. 741, 744 (S.D.N.Y. 1980) (finding copying of four notes out of 100 bars of music to be fair use); see generally NIMMER, supra note $34, \S$ $13.03[\mathrm{~A}][2]$.

36. See, e.g., Toulmin v. Rike-Kulmer Co., 137 U.S.P.Q. 533, 534-35 (S.D. Ohio 1962) ("The use of one sentence and part of another [took] neither a substantial nor material part of the [original work], did not in any degree prejudice the sale, diminish the profits or supcrsede the objects of the orignial work, and was thus a 'fair use' thereof. ... [T] his is a clcar case of de minimis.") One commentator finds the courts' mixed terminology to be unfortunate. Nimmer argues that "the meaning of "fair use' is thereby rendered confusingly ambiguous." NIMMER, supra note 34 , 13.03[A][2]. The fact that something is not substantial, he argues, "may simply mean an insubstantial similarity regardless of defendant's use, or it may mean substantial similarity that would constitute an infringeinent but for the particular purpose and use of the resulting work by the defendant." Id.; see also Linda J. Lacey, Of Bread and Roses and Copyrights, 1989 Duke L.J. 1532, 1545 n.65 ("The idea that a de minimis copying may constitute fair use has existed for decades and was apparently endorsed by Justice Blackmun in the Betamax case.... Blackmun gave examples of situations in which de minimis copying was appropriate, sucl as photocopying newspaper clippings or pinning quotations on a bulletin board." (citation omitted)). But see Nelson v. PRN Prods., Inc., 873 F.2d 1141, 1143 (8th Cir. 1989) (rejecting an attempt to conflate the concept of substantial similarity with that of fair use). In any case, for the purposes of the market-failure rationale, both terms mean essentially the same thing: the use was too slight to expect the parties to work out a license in advance. See infra Part II.B. 
II

\section{The Market-Failure Paradigm}

Under the market-failure explanatiou for fair use, however, this preferred treatment given to users of fragmented copies is in flux. The market-failure paradigm provides a solid justification for courts to grant free use to fragmented copies in the print world. It explains fair use as a necessary corrective response to various costs that prevent the copyright marketplace from functioning properly. In the market for fragments, because owners have never developed an efficient way to license copies, it has been easy to justify fair use as a remedy for the failed market. However, new technologies generally make licensing markets increasingly feasible. The Internet and other digital environments break down many of the logistical barriers that have prevented owners from licensing fragmented content in the past. By focusing on this new-found ability of owners to overcome market barriers, the Task Force argues that fair use is of diminished importance in the digital realm.

\section{A. The Basic Market-Failure Paradigm}

An economic analysis of the copyright market rests on a fundamental premise that the purpose of copyright law is to create a workable exchange mechanism for creators and users. These laws privatize an otherwise public commodity in order to ensure a market where none would normally exist. ${ }^{37}$ The market-failure paradigm, in turn, posits that fair use fuuctions primarily as a tool to address problems that may impede the functioning of this new market. ${ }^{38}$

\section{The Copyright Laws Enable a Private Market}

Expressive content, as a type of information, is a public good..$^{39}$ That is to say, creative works exhibit the two qualities that economists have identified to characterize public goods. ${ }^{40}$ First, consumption of this type of good is non-rivalrous: When one person uses it, she does not deprive anyone else of use of the same information. Second, absent regulation or other interference in the market, the owner will find it difficult to exclude people who have not paid from enjoying the benefits of the content. ${ }^{41}$ According to the economic model of public goods, absent an intellectual property system, market participants will

37. See Robert P. Merges, et al., Intellectual Property in the New Technological AGE 12-14 (1997) (discussing generally the way that intellectual property rights in the United States serve to alleviate a public goods problem).

38. See generally Gordon, supra note 9.

39. See, e.g., Robert Cooter \& Thomas Ulen, Law and Economics $102-03$ (2d ed. 1997)

40. See id. at 40.

41. See infra note 44 for discussion of the potential effect of digital environinents on this second factor. 
under-produce expressive works. ${ }^{42}$ For instance, if we did not give any copyright protection, publishers might just as well wait for someone else to publish a successful work. Then they could reprint it themselves and save the costs of paying royalties. Likewise, consumers could simply make their own copies, thereby paying only the cost of the physical reproduction. In such a system, authors would never receive payment adequate to underwrite their work, and society's creative output would suffer. ${ }^{43}$ In order to maximize production of creative content, therefore, the copyright laws aim to remove expressive works from the realm of public goods. ${ }^{44}$

In order to privatize the good, the laws must counteract one of the elements that make the goods public. The first element, non-rivalrous consumption, is an inherent benefit of expressive works. There is no reason to interfere with this aspect, nor is there any practical way to do so. Rather, the copyright system counteracts the second element by allowing a copyright owner to exclude nonpaying individuals from the benefits. The copyright system gives content creators control over their works specifically to create a workable market between the content creator and potential users. ${ }^{45}$ As a result, the copyright-exchange mechanisms function similarly to those in other markets. ${ }^{46}$

42. See COOTER \& ULEN, supra note 39 , at 40 (economically rational firms will not produce the optimal amount of public goods in an unregulated market).

43. Of course, there are other systems in place in our society that would ensure some creation. For instance, the tenure system at most universities forces academics to produce and provides them with reward for that production. Although such systems will ensure creation of certain types of works, most creation would go without reward.

44. Theoretically, another solution would be to finance creation publicly, that is, the government could produce these works. In fact, our government provides many public goods, such as national defense, scientific research, and weather satellites. But, for obvious reasons, we have chosen a different path for creative works.

45. There is soine reason to believe that the digital market itself now allows owners to control the non-excludability eleunent of public goods. This evolving market now grants copyright owners substantial new powers to control dissemination of their own works. Eric Schlachter has described numerous ways in which content owners can control their works without relying on copyright law. See Eric Schlachter, The Intellectual Property Renaissance in Cyberspace: Why Copyright Law Could Be Unimportant on the Internet, 12 BERKELEY TECH. L.J. 15, 38-49 (1997) (arguing that copyright laws may be unnecessary because content owners will take advantage of certain aspects of the new medium to protect their works through technological, rather than legal, means); see also Mark Stefik, Shifting the Possible: How Trusted Systems and Digital Property Rights Challenge Us to Rethink Digital Publishing, 12 Berkeley Tech. LJ. 137, 138 (1997) ("With the development of trusted system technology and usage rights languages with which to encode the rights associated with copyrighted material, authors and publishers can have more, not less, control over their work.")

With the content owners' new-found controls, some might argue that the goods are no longer public at all. To present the particular problems that disturb a market, goods inust have both of the elements discussed above: non-rivalrous consunption and non-excludability. Without the public goods problem, perhaps there is no need for fair use or for copyright law at all. In fact, a similar line of reasoning has led some commentators to just such a conclusion: Because copyright law and digital technology each perform the same function, there is no need for copyright law in this environment. See, e.g., Schlacter, supra, at 49. 


\section{Fair Use Corrects Imperfections in This Private Copyright Market}

If the market between a copyright-holder and a user is perfect, the two parties will be able to agree on a price and enter into a voluntary bilateral contract. ${ }^{47}$ In such a case, economic insight indicates that policy-makers need not worry: ${ }^{48}$ The owner receives a reward for creation, and the user will be able to use the materials in potentially productive ways. ${ }^{49}$ Having allowed owners to close out free-riders, the copyright system need take no further step. However, in certain circumstances, imperfections in the market interfere with efficient outcomes. ${ }^{50}$ When substantial transaction costs or other imperfections are present in a given

However, there is an inherent benefit to public goods. The fact that they are non-rivalrous is a tremendous source of value. In fact, I would argue that this value provided the impetus for Congress to create copyright law in the first place. Expressive works support the progress of science and the useful arts because the knowledge becomes more useful the more people who experience it. Furthermore, this non-rivalrous nature created many of the external benefits discussed infra Part III.B. Most importantly, as we will see, fair use provides a way to put a given use back into the realm of public goods.

We should inquire, then, if there is a similar check on digital technology that allows us to retain some of the benefits of publie goods. Eventually, technology may allow users to ignore content owners' controls and thus copy without paying. Theoretically, such circumvention provides a way for users to render a type of use public. However, circumvention technology presents at least two major problems for this policy goal. First, it does not allow any ready way for policy-makers to control the process and to allow only deserving uses to retain public status. Second, the United States and the World Intellectual Property Organization have been pushing to make illegal any device or program designed to circumvent digital rights management technology, apparently even if the use would otherwise be fair use. Without fair use or other circumvention capability, we lose the ability to make the minor adjustments that temper the content-owner's monopoly power and that preserve the benefits of public goods.

46. For further economic insights on the copyright marketplace, see, e.g., COoTER \& ULEN, supra note 39, at 125-28; Gordon, supra note 9; William M. Landes \& Richard A. Posner, An Economic Analysis of Copyright, $18 \mathrm{~J}$. LEGAL STUD. 325 (1989).

47. Substantial complications arise in even a simplistic application of this model to the copyright world, in part because of the presence of the public goods problem. Not only is the original content naturally a public good, but many types of secondary uses have the public goods characteristics as well. See infra Part III.B.

48. Outside interferenee in a perfectly functioning market generally cannot help to obtain a more efficient allocation of resources. See generally Coase, supra note 13.

49. Note that this claim oversimplifies the issue. If we allowed the user free use of the material, the user would have more resources to spend on other activities, including perhaps the acquisition and distribution of other pieces of intellectual property. See infra Part IV for discussion of the idea that there may be significant distributional, as opposed to efficiency, concerns that favor a transfer even in the presence of complete alignment of interest. Although all transfers that promote efficiency would occur in a perfect market, we may want to distribute wealth in other cases as well. Accordingly, a potential function of fair use is to encourage transfer even when not efficiencyenhancing, for purely distributional reasons. See, e.g., Merges, supra note 8, at 133-34. Professor Gordon notes that " $[t]$ here may also be occasious in which it is normatively inappropriate to use even a perfectly functioning market." Gordon, supra note 9, at 1607 n.39. For instance, "[i]f the defendant's interest impinges on a first amendment interest, relying upon the market may become particularly inappropriate; constitutional values are rarely well paid in the marketplace and, while the citizenry would no doubt be willing to pay to avoid losing such values, it is awkward at best to try to put a 'price' on them." Id. at 1631.

50. See Coase, supra note 13, at 15-19. Coase refers to these imperfections as transaction costs. 
market, the market will not necessarily produce the most efficient outcome. In such cases, some sort of outside interference (governmental or otherwise) may help to ensure a more beneficial result. ${ }^{51}$

In the copyright market, analysts have identified many sources of imperfection. These commentators have focused primarily on the tracing and bargaining costs that pervade this marketplace. Tracing costs ${ }^{52}$ result because the copyright owner is rarely present when the subsequent user decides to copy the work. The identity of the owner often will not be obvious from the face of the copyrighted work, and the owner will rarely be easy to reach. Bargaining costs more obviously refer to the expense of negotiating with a distant party. In the absence of a fully functioning and efficient sub-market in the type of content sought to be used, such costs may exceed the benefits the transfer would otherwise create. ${ }^{53}$ If so, the transfer will not occur.

The fair-use doctrine can be seen as an attempt to respond to such failures in the copyright market. ${ }^{54}$ In general, the market will yield the result copyright policy dictates. However, in situations in which structural imperfections lead to market failure, the goal of payment to the content owner is unattainable, and fair use provides a correction to the market that preserves at least some of the overall copyright goals. ${ }^{55}$ As Professor Goldstein has explained:

51. See, e.g., Guido Calabresi \& Douglas Melamed, Property Rules, Liability Rules, and Inalienability: One View of the Cathedral, 85 HARv. L. REv. 1089, 1111-15 (1972). The authors carry the idea so far as to say that in certain circumstances, the most economically efficient solution may be to forbid bargaining altogether.

52. See Landes \& Posner, supra note 46 (identifying tracing costs as consisting of determining exactly who owns the copyright and tracking down that person, and concluding that these costs explain certain limitations on the copyright, such as the limited term of years).

53. See, e.g., Gordon, supra note 9 , at 1608.

54. See Gordon, supra note 9, at 1605. Although Gordon first expounded this market-failurc paradigm in 1982, the market function has long been central to the fair use analysis. From the earliest fair-use cases, courts have looked to the effect of potential infringements on the relevant markets. When he first introduced the concept of fair use into the copyright doctrine, Justice Story directed courts to look to the "degree in which the use may prejudice the sale, or diminish the profits, or supersede the objects, of the original work." Folsom v. Marsh, 9 F. Cas. 342, 348 (D. Mass. 1841) (No. 4901). The greater the likelihood of such adverse economic effect, the less likely a court should be to find a use fair. The Copyright Act of 1976 includes this market sensitivity in its formulation in at Icast two ways. The first of the four fair-use determination factors exphicitly references the potential commercial nature of the use. See 17 U.S.C. $\$ 107(1)$ (1995). Additionally, the fourth factor points to the effect the use has on the market value of the original. See 17 U.S.C. $\$ 107(4)$ (1995). The Supreme Court has stated repeatedly that this last factor is the most important in the analysis. See, e.g., Harper \& Row, Publishers, Inc. v. Nation Enterprises, 471 U.S. 539, 566 (1985); NiMMER, supra note 34, \$ 13.05[A][4]. But see American Geophysical Union v. Texaco Inc., 60 F.3d 913, 926 (2nd Cir. 1994) (suggesting that the Supreme Court, in Campbell v. Acuff-Rose Music, Inc., 510 U.S. 569 (1994), may have abandoned the idea that the fourth factor is of heightened importance).

55. Professor Gordon posited that there are three concerns to weigh before finding fair use: first, author incentives; second, user access; and third, whether the defendant can "appropriately purchase the desired use through the market." Gordon, supra note 9, at 1601. See id. at 1605 ("[F]air use should be interpreted as a mode of judicial response to market failure in the copyright context, 
Fair use operates on the pragmatic notion that half a loaf is better than none: without it, the copyright owner would get no revenues because costs of negotiating a license are insuperably high, while the prospective user would for the same reason get no copy; with it, the copyright owner still gets nothing, but the user at least gets to make a copy..$^{56}$

\section{B. Fragmented Copying and Market Failure}

Through the lens of a market-failure analysis, it is easy to justify the courts' response to fragmented literal copying of print media. When a particular borrowing is minimal, it is less likely that a market would form for the transfer, less likely that an author would demand a payment for its use, and less likely that certain benefit-producing users would want to pay as much for the use. The paradigm also helps to explain the divergent explanations courts have given to allow the copying. ${ }^{57}$ Some courts, framing the issue from the content owner's standpoint, will describe the infringement as de minimis: It is not enough of a taking that the owner could have received any benefit from it. Others, framing the issue from the user's viewpoint, will describe it as a fair use: Though the copying is at least marginally valuable to the user, there is no appropriate mechanism through which that user can pay the owner.

The example laid out in the introduction, with a slight modification, illustrates such a market failure. Suppose Irene had found the Langston Hughes article in a print magazine, and she wanted to follow faithfully the copyright licensing process. In the absence of a fair-use justification, she would have to determine the identity of the copyright owner. She might first call the magazine (quite likely long distance). Suppose the article's author, rather than the magazine, maintains the copyright. She would then have to find that person and bargain over a price. Of course, that process would only cover the text of the article. For the poems, she would have to contact Langston Hughes' estate, or perhaps his

and...the presence or absence of the indicia of market failure provides a previously missing rationale for predicting the outcome of fair use cases.").

56. GolDSTEIN, supra note 4, at 170 . Note that this solution corresponds to the most basic notion of achieving Pareto efficiency. A solution is Pareto efficient if it makes one party better off without making any other parties worse off. See COOTER \& ULEN, supra note 39, at 12. For further discussion of the need to encourage transfer even without payment, see Merges, supra note 8 , at 133 ("A voluntary bilateral exchange ... is important-but exchange itself (which might better be called dissemination) is more important still."). One court explained that, based on the constitutional mandate of the copyright clause, courts "must occasionally subordinate the copyright holder's interest in a maximum financial return to the greater public interest in the development of art, science and industry." Rosemont Enterprises, Inc. v. Random House, Inc., 366 F.2d 303, 307 (2d Cir. 1966) (quoting Berlin v. E. C. Publications, Inc., 329 F.2d 541, 544 (2d Cir. 1964)).

57. See supra notes 34-36. 
publisher, each of his heirs, etc. This process might involve a significant investment of time and money. Assume that the use of the materials here provides $\$ 8$ worth of education to the students. Further, as indicated above, assume the owner will license the use for $\$ 3$. In a costless environment, she would pay to license the use. However, if the search and bargaining process, the telephone calls, etc., cost more than $\$ 5$, the transfer will cost more than it is worth. Consequently, she would not show the picture to her class, even though the transfer of display rights could have generated a net benefit (i.e., the benefit to the students would be greater than the cost to the magazine).

Although transaction costs are inherent in almost any transaction, whether for an entire article or just a sentence, the tracing and bargaining costs will disproportionately affect fraginented copying. The costs will be similar regardless of the length of the quote, while the value a transfer can generate may be less for sinaller chunks of content. Further, the presence of these tracing costs undercuts both intermediate aims of copyright policy: The creator receives no additional incentive, and public access cuts off at its current level. As a response to this failure, fairuse protection provides for public access. If the teacher uses the materials uotwithstanding the copyright barrier, public access will increase without injuring the copyright creator's incentives (because the creator would not have received any coinpensation anyway).

\section{The Effect of Emerging Markets on the Scope of Fair Use under the Market-Failure Paradigm}

In many markets, tracing costs are miniznal, and bargaining costs are limited to the time it takes the two individuals to discuss the sale. In a modern American supermarket, for instance, there is no question to whom one should pay a dollar for the bunch of bananas one wants, and most customers never bargain at all. At a car dealership, the customer may spend more time bargaining, but that customer knows to whom to talk and pay the money. To the exteut that courts rest their rationale for fair use on tracing and bargaining costs, then, they may be less likely to grant fair use when a particular copyright market develops that more closely resembles these other types of markets. ${ }^{58}$

58. New forms of technology will often reduce the costs that interfcre in given markets. Of course, these new technologies are generally designed to achieve just some such effect. Examples include moveable-type printing presses, video cassette recorders, digital audio tapes, fax machines, and so on. In one of the more dramatic examples, the photocopier has worked a huge change in the landscape for copyright owners and users. With the advent of this new machine, users could suddenly make copies at a small fraction of the cost they would have expended previously (such as the time it might take to write out a new copy by hand). The advent of the photocopicr did not address per se the tracing or bargaining costs inherent in the market, that is, it did not directly allow users to track down 
In fact, two circuit courts recently have used the emergence of a newly developed licensing market to limit drastically the scope of fairuse protection. ${ }^{59}$ The Second and Sixth Circuits each examined uses in the context of a new organization (the Copyright Clearance Center) that had created a new type of market for scientific and technical articles. Both courts denied fair use to activity that likely would have received favorable treatment in the past.

The Copyright Clearance Center ("CCC") facilitates licensing of individual articles from various copyright holders. ${ }^{60}$ Thus far, the CCC has focused on articles in scientific and technical journals. It aims to serve a function in this market similar to that which the American Society of Composers, Authors and Publishers ("ASCAP") serves for musical compositions. ${ }^{61}$ An organization might get a blanket license from the CCC to copy articles the CCC controls, or it might pay fees for the copies on a per-copy basis. The CCC aims to distribute the proceeds fairly among the various authors it represents. Users can make copies themselves and pay for them much more cheaply and quickly than if they called the owner and ordered a new copy of the work. By paying the CCC a reasonable royalty for the right to copy, the user divides the new-found surplus with the copyright owner. Of course, the CCC's royalty system also reduces drastically the tracing and bargaining costs for this particular market.

The dispute in American Geophysical Union v. Texaco Inc. ${ }^{62}$ focused on the practices of Texaco's in-house researchers. Texaco maintained a library that subscribed to various scientific and technical journals. The library circulated the journals among its 400 to 500 researchers. When researchers found that a particular article would be of use in their work, they would copy the article or ask another Texaco employee to copy that article. ${ }^{63}$

The Second Circuit acknowledged that Texaco had a valid marketfailure rationale for this practice in the past. Previously, there had never been "a simple or efficient means to obtain single copies of individual articles." ${ }^{64}$ Publishers had traditionally released individual articles only

owners and bargain with them. Nonetheless, an institution, the Copyright Clearance Center, eventually (and predictably) arose to take advantage of the new efficiency the photocopier created.

59. See Princeton Univ. Press v. Michigan Document Servs., Inc., 99 F.3d 1381, 1387-88 (6th Cir. 1996), cert. denied, 117 S. Ct. 1336 (1997); American Geophysical Union v. Texaco Inc., 60 F.3d 913, 930-31 (2d Cir. 1994).

60. See American Geophysical Union, 60 F.3d at 929 n.16; see also GoLDstels, supra note 4, at 219-23 (discussing the Copyright Clearance Center's creation and rise in influence).

61. See Goldstein, supra note 4, at 68-76 (discussing the historical and legal development of the American Society of Composers, Authors and Publishers).

62. 60 F.3d 913 (2d Cir. 1994).

63. See id. at 915 .

64. Id. at 927 . 
in the format of a complete journal volume. Consequently, Texaco argued, its practice of copying individual articles did not affect any judicially cognizable market. The court agreed that "[o]nly an impact on potential licensing revenues for traditional, reasonable, or likely to be developed markets should be legally coguizable when evaluating a secondary use[]." ized use should be considered 'more fair' when there is no ready market or means to pay for the use, while such an unauthorized use should be considered 'less fair' when there is a ready market or means to pay for the use." 66

Nonetheless, the court decided against Texaco. The court's reasoning turned on the new market presence of the CCC. The court concluded that the publishers involved in the formation of the CCC had created "a workable market for institutional users to obtain licenses for the right to produce their own copies of individual articles via photocopying." ${ }^{167}$ In other words, the publishers had set up a market in which the transaction costs of paying for the given use were minimal. On the strength of this observation, the court found that Texaco had no valid fair-use defense, even though the scientists were engaged in research. ${ }^{68}$

In Princeton University Press v. Michigan Document Services, ${ }^{69}$ the Sixth Circuit adopted this sort of reasoning and extended it to the context of commercial preparation of course readers. This case concerned a copy shop that served the academic community at the University of Michigan. The copy shop prepared course packs ${ }^{70}$ for various classes. The owner of the shop refused to request permission from, or to pay licensing fees to, the text book publishing companies from which he copied the materials for the course packs. ${ }^{11}$ The Sixth Circuit found that this defendant's activities did not merit a fair use, even though the ultimate purpose of the copying was education.

As in American Geophysical Union, this court focused on factual issues that showed that tracing costs were minimal. The court noted that the three plaintiff publishing companies each had a department that

65. Id. at 930 .

66. Id. at 931 .

67. Id. at 930 .

68. See id. at 931-32.

69. 99 F.3d 1381 (6th Cir. 1996), cert. denied, 117 S. Ct. 1336 (1997).

70. The court explained:

Thanks to relatively recent advances in technology, the coursepack ... has become almost as ubiquitous at American colleges and universities as the conventional textbook.... [B]y selecting readings from a variety of sources, the professor can create what amounts to an anthology perfectly tailored to the course the professor wants to present. Id. at 1384.

71. See id. 
processed requests from these copy shops. ${ }^{72}$ Furthermore, the copy shop could have licensed the use through the CCC. "Where ... the copyright holder clearly does have an interest in exploiting a licensing marketand especially where the copyright holder has actually succeeded in doing so- 'it is appropriate that potential licensing revenues for photocopying be considered in a fair use analysis." "73 In this instance, the three plaintiffs together earned nearly $\$ 500,000$ per year in copy shop permission fees. The court concluded that "the destruction of this revenue stream can only have a deleterious effect upon the incentive to publish academic writings." 74

These two cases indicate that new licensing markets can work to constrict fair use and, specifically, to shorten the length of a copy that might fall within the justification for fair use as a fragment. Even before the decisions, it was clear that copying an entire journal or textbook would generally constitute infringement. However, sporadic copying of individual articles may have been permissible. The market created by the CCC lowered the threshold of permissible free copying, at least from scientific and academic journals, so that copying an entire article or section of a book is infringement, while copying a smaller amount might still be fair use.

The rationale on which these courts relied potentially has implications that extend far beyond the market for scientific and academic articles. In fact, if there were some efficient way to link up every paragraph, every sentence, or every word with the content owner, the tracing-costs rationale for fair-use protection would largely disappear, even for highly fragmented uses. The Internet could provide precisely this effect. As Professor Goldstein has explained, digital environments "may reduce the transaction costs of negotiating licenses not only for complete works, such as journal articles, but for small fragments as well."?5

Just as publishers have already worked out a system to license uses of technical articles, the Internet conceivably allows all copyright owners to license all digitally available content. ${ }^{76}$ It is possible to encode each bit of content with the information required to ensure payment to the appropriate content owner. The user need not do any research at all in order to determine the identity of the owner. Rather, the user merely needs to click on a box to agree to pay a given amount. Furthermore,

72. See id.

73. Id. at 1387 (quoting American Geophysical Union, 60 F.3d at 930).

74. Id. at 1391.

75. Goldstein, supra, note 4, at 223-24. Professor Merges has described the effect of digital uses more generally: "If the market-making capacity of institutions such as the CCC makes such a dent in market failure, digital technologies will obliterate the fair use defensie entirely." Merges, supra, note 8 , at 132 .

76. See GoldSTEIN, supra, note 4, at 224 (examining the likely manifestation of this market). 
various organizations and entrepreneurs are developing increasingly efficient payment structures for increasingly minor transactions. ${ }^{n}$ In the typical situation, each user would have her own account with a service provider. She would pay in to that account, and each time she purchased content or access time to some web site, the system would automatically debit her account the $\$ 3$ or $\$ 0.12$ or any other price and credit that amount to the owner.

The Task Force would end its analysis here. Because the copyright owner has established a working market and a position within that market, and because the copyright system seeks to reward creation, the Task Force would conclude that fair-use protection is unnecessary.

III

\section{Market Failure Persists in the Digital Market FOR FRAGMENTED COPIES}

The Task Force's implicit focus only on the content owner's market position sells copyright policy short. The copyright system must balance two competing interests: those of creators (incentives) and those of the public that wants to use the creation (access). The Internet will eventually allow owners to create a licensing market in which they can put coded information on-line and extract payments from most endusers with minimal transaction costs. This situation indicates that the copyright owner's access to users of copyrighted matter is relatively cost-free and the owner can now bargain with certain users, which certainly serves the incentives goal. However, other imperfections can prevent certain users' participation in that same market, even when their uses would be efficient from society's standpoint. In order to preserve the access goal, we must not assume that each working licensing market is inherently perfect. Taking the market-failure analysis to its logical conclusion, we must continue to allow a fair use to those users who encounter intractable market failure.

At least three types of market failure will persist in the digital market despite the emergence of ostensible methods to license fragments. First, lingering bargaining costs will interfere directly with a content owner's ability to set up a market for fragments that is as efficient as the Task Force envisions. Second and third, the presence of either externalities or anti-dissemination motives can interfere with a given user's capacity to produce socially efficient uses.

77. See, e.g., Tom Steinert-Threlkeld, The Buck Starts Here, WIRED, Aug. 1996, at 132 (discussing various plans for digital money systems and the hurdles those plans face). 


\section{A. Lingering Bargaining Costs}

The first source of market failure for fragmented copying in a digital environment will arise from the difficulty inherent in valuation of such transfers. Suppose a given article is worth $\$ 5$ to copy. The author will likely argue that, by copying only one paragraph, the user has chosen exactly the part that is most valuable, at least to that user. After all, that is why the user has chosen the paragraph. So the author will argue that while the fair price may be less than $\$ 5$, it should not be much less, e.g., \$3. Further, if the user wants only one sentence, then the author might say that the user has taken the one valuable sentence from that paragraph, and should pay $\$ 2$. The user, on the other hand, thinks of her own work as the product. She will tend to think of her research costs in the aggregate. For instance, a given user may have $\$ 30$ to spend on materials for a research project with 100 projected sources. The portion she wants to copy from this one work will comprise only a tiny portion of her completed project.

Although these parties can theoretically bargain to a resolution, the costs will undercut precisely the presumed value of the new medium. Unfortunately for the contracting parties, every fragmented copy will likely be different. If one could agree that a $\$ 5$ article with 500 words should cost $\$ .01 /$ word to copy, the answer would be simple. In reality, however, user A may copy three sentences from different parts of the article, while User B copies four sentences in a row from one paragraph, and User $C$ copies four separate paragraphs and two individual sentences. When every transaction is unique, it is much less likely that the parties will agree that some pre-determined algorithm results in a just price. ${ }^{78}$ Because the parties must bargain with each other directly, the value of a potential digital-realm market diminishes.

78. One solution to this problem might be a blanket licensing scheme like those ASCAP (or the CCC) provides certain users, under which the user buys the right to use any ASCAP works or any part thereof. Because the owners have aggregated the sources, the initial bargain will be much easier for the parties. Further, the parties need not repeat the negotiation wastefully. Unfortunately, such a solution is entirely theoretical and unlikely in the foreseeable future. The range of content and of content-providers on the Internet is simply far too vast for any umbrella scheme. ASCAP, by comparison, only covers one aspect of the music copyright industry, and only some owners at that. Further, those owners are not always satisfied with ASCAP's imperfect payment schemes. Application of this model to the Intemet is exceedingly difficult at best. That said, we should certainly try to encourage these more efficient mechanisms. To the extent that content owners actually have set up a system that removes the bargaining problem for a given class of users, courts should be sensitive to that fact. Subject to the further analysis suggested in this Comment, courts should follow the recent precedent and require payment. See supra Part II.C. for further discussion of the purpose and workings of the $\mathrm{CCC}$. 


\section{B. Externalities}

A second type of market failure will result from the fact that a given user's willmgness to pay may not reflect all the social benefits that flow from the use. To ensure an efficient outcome, the bargaining parties must bear all the costs and reap all the benefits of the bargain. ${ }^{79}$ If all costs and benefits are not "internal" to the transaction, then the willingness of the parties to agree on a certain price will not necessarily reflect the true social value. Ideally everyone who will be affected by a transaction should participate in the negotiations and any exchanges. However, where the potential beneficiaries or injured parties are numerous, geographically separated, etc., the affected parties cannot possibly all sit down at the bargaining table to air their viewpoints. ${ }^{80}$ In some instances, the parties will be able to internalize the costs and benefits. A typical way parties can internalize a copyright use is through commercial exploitation of that use. If the benefits are large, nebulous, or noncommercial, however, the copyright user may not be able to internalize them. In such a case, intractable market failure will develop.

Irene's experience with the Langston Hughes quotations presents a good example of how exterualities can affect this marketplace. The only parties to a potential transfer of the right to copy and display the work will be Irene and the copyright holder, but the individual students in the class are the intended beneficiaries. Access to the Langston Hughes quotes will aid in their understanding of our literature and culture. U1timately, the students' knowledge benefits society and each of its members. The important question for the current analysis then becomes: Will Irene successfully "interualize" this potential benefit of the transfer? In the absence of a specific fund set up to pay for additional materials of this sort, ${ }^{81}$ there is good reason to assume that she will not effectively

79. See COOTER \& ULEN, supra note 39 , at 38-39.

80. An archetypal example of this phenomenon is a power plant that produces pollution in a city. The potential beneficiaries of pollution controls are all the residents of the city who otherwise breathe the smog produced. But it would be entirely too costly to bring all of the residents to the bargaining table. See id, supra note 39, at 99-100 ("Private bargaining is unlikely to succeed in disputes involving a large number of geographically dispersed strangers because communication costs are high, monitoring is costly, and strategic behavior is likely to occur. Large numbers of land owners are typically affected by nuisances, such as air pollution...."). A typical solution is for the govcrnment to try to represent all of the collective interests.

81. A theoretical solution to this problem would be for the school to have a fund to pay for uses of this sort. The idea would be that the members of society pay taxes (or tuition) to the school that refiect the economic value the school will add to the community (or to their children). The school then can be an effective proxy for the community's interest. Irene's school had no such fund. Even if it did, however, the idea that the school could internalize the benefits down to this level is dubious. Like the copyrighted works themselves, education is a quasi-public good. It is non-rivalrous, and the benefits spread across society in a way that the provider cannot control. Consequently, like other public goods, each incremental source of education is systematically undervalued. For instancc, without the rules that we have in place, a large segment of the population would not seek education 
internalize the benefit, for she is not in a position to recapture the benefit from the children or from society generally. If Irene does not effectively internalize the benefit, then her incentives in the bargaining process will understate the value of the transfer. As above, assume that it is possible to determine that the benefit to society will eventually be $\$ 8$. Also assume that, based on her own incentives, the teacher is only willing to spend $\$ 1 .^{82}$ Remember that the price to license the use is $\$ 3$. A transfer would generate a surplus of at least $\$ 5^{83}$ and would thus be desirable. However, the transfer will not occur, because the teacher will not pay the market price. Given these facts, the market has failed to produce the outcome that would best reconcile copyright's public and private goals.

Some may argue that the courts, in American Geophysical ${ }^{34}$ and Michigan Document Services ${ }^{85}$, have already rejected or severely restricted the potential reach of an externality analysis. Those two cases imvolved, respectively, research and educational uses. On the surface, it might appear that those fact patterns presented the best case for externalities. Consequently, because the courts rejected fair use, it might seem that the ability to license will trump the presence of third-party benefits. However, I will argue in the following sections that there are two important distinctions to make among benefit-producing uses. First, a beneficial use may be distributive, meaning that it merely creates a wider audience, or it may be transformative, in the sense that it also adds expressive meaning to the original. Second, a user may or may not be able to internalize the benefits and thus eliminate the externality. A closer analysis shows that the uses in the two cases above fall into the category of benefit-producing uses least deserving of fair-use protection. As such, courts and policy-makers should not rely on these cases when

past elementary school. Consider the past experience of farm kids who stopped going to school after a certain age to help on the farm. This behavior reflected perfectly rational short-term behavior for the parents, because they needed help immediately with the harvest. The fact that society generally lost the benefit of an educated population simply did not weigh heavily into the parents' decision. Especially when dealing with a resource that is this conjectural (as opposed to obvious set needs such as textbooks), it is likely that the decision-makers will not fully appreciate all the values involved.

82. Through perfect price differentiation, the owner might be able to capture the value of this $\$ 1$, even if the average market price would be higher. See Hal R. Varian, Differential Pricing and Efficiency, FIRst MONDAY, June 1996, available at <http://www.firstmonday.dk/issues/issue2/ different/>. However, perfect price differentiation is almost impossible, requires other transaction costs, may run into problems with the antitrust laws, and should not be countenanced in fair-use analysis unless it is present.

83. The total surplus will be closer to $\$ 8$. The cost of producing this copy will be close to $\$ 0$ (as with most digital copies). Consequently, the $\$ 3$ the magazine receives falls within total surplus as well. This part of the surplus would represent the reward the copyright framework grants to creators.

84. 60 F.3d 913 (2d Cir. 1994).

85. 99 F.3d 1381 (6th cir. 1996), cert. denied, 117 S.Ct. 1336 (1997). 
considering the highly transformative fragmented uses likely to dominate uses on the Internet.

\section{Distributive v. Transformative Uses}

Many kinds of uses can generate benefits for copyright goals. Commentators have long distinguished between end uses and secondary uses. ${ }^{86}$ An end use occurs when the user consumes the original, for instance by reading a book or by watching a movie. ${ }^{87} \mathrm{~A}$ user generates a secondary use when she copies the original in order to pass the expressive content on to a third party. For the purposes of effective externality analysis, I believe it is important to make an additional distinction between two different types of secondary uses. The first, which I call distributive, provides that a given user might succeed in distributing the original work to a larger audience than would otherwise be possible. The second type, often central to a court's copyright policy analysis, is a transformative use, or a secondary use that transforms the original, thereby creating new creative content. Both distributive and transformative uses can yield benefits that the parties may not be able to internalize.

Distributive uses serve the important copyright policy interest of increased access. For instance, even though it did not receive a fair use, ${ }^{88}$ the copy shop in Michigan Document Services ${ }^{89}$ helped to broaden the audience for certain academic texts. Having assigued given readings to their students, the professors encouraged a wider distribution of the works in question. When it made the actual copies, the copy shop assisted in this process, ${ }^{90}$ even though it was not responsible for any of the

86. For example, Professor Netanel distinguished between consumptive and transformative uses. See Netanel, supra note 12, at $311 \mathrm{n} .112$. Consumptive uses are those in which the user uses the work in the way the author intended to sell it, for example, reading a copyrighted book, watching a copyrighted movie, etc. As discussed above, a transformative work results when the subsequent user creates a new work incorporating the earlier one in a new light. Professor Samuelson refers to these categories as intrinsic and productive. "Productive uses bring a new work, such as a critical review that quotes from a copyrighted novel, into the world, thereby adding to the corpus of knowledge.... An intrinsic use merely consumes the work in the same way as if a copy had been purchased." Samuelson, supra note 18 , at 61 .

87. It is important to note that even end uses can produce externalities. Take for example the children in Irene's class. As opposed to Irene's use, their use is purely consumptive. The exposure to Hughes' work benefits them personally, but it also eventually benefits society generally. The country benefits from a populace that has an appreciation for the arts. Of course, this benefit resonates quite strongly with the ultimate purpose of copyright. See supra Part I.

88. See infra Part 11I.B.2.b for a discussion of the effect of the high degree of commerciality of the particular use in this case.

89. 99 F.3d 1381 (1996), cert. denied, 117 S. Ct. 1336 (1997).

90. Arguably, the use in American Geophysical Union had some distributive qualities as well. Certainly, Texaco was the end user. However, the copying did not directly facilitate this end use. Rather, the court emphasized that the copying was "a systematic process of encouraging employee researchers to copy articles so as to multiply available copies while avoiding payment." American 
creative content or the expressive message of the works. Irene's example shows how even fragmented copies can have distributive value. Irene found the quotes and ensured their distribution to a larger audience, i.e., the children. As explained above, she thereby created numerous benefits that extended to parties other than herself and the copyright owners.

Transformative uses, in addition to ensuring a wider audience, add new expressive content to the original. A recent Supreme Court case demonstrates the importance of this content creation. In Campbell $v$. Acuff-Rose Music, Inc., ${ }^{91}$ the Court reviewed 2 Live Crew's use of Roy Orbison's song "Oh, Pretty Woman!" 2 Live Crew had created a raunchier version of that song. When the band contacted Roy Orbison and Acuff-Rose, offering to pay royalties on the song, Acuff-Rose refused to grant a license. ${ }^{92}$ The Court extended fair use analysis to this situation, in large part because 2 Live Crew fundamentally changed the original song and created a new expressive work.

The Court ruled that the question of whether or not a use is transformative is central to any analysis under the first factor of Section $107 . .^{93}$ The Court explained that the purpose of the analysis of the first factor "is to see... whether the new work ... adds something new, with a further purpose or different character, altering the first with new expression, meanmg, or message."94 Transformative works "lie at the heart of the fair use doctrine's guarantee of breathing space within the confines of copyright."95 Applying this test to the case at hand, the Court explained that parody "has an obvious claim to transformative value .... [I]t can provide social benefit, by shedding light on an earlier work, and, in the process, creating a new one." 96 The Court explained that the words in the infringing song "can be taken as a comment on the naiveté of the original of an earlier day, as a rejection of its sentiment that iguores the ugliness of street life and the debasement that it signifies." 97 Focusing on the transformative value generated, as well as on the anti-dissemination motive inherent in this market, ${ }^{98}$ the

Geophysical Union v. Texaco Inc., 60 F.3d 913, 920 (2d. Cir. 1995). In fact, the court concluded that "the predominant archival purpose of the copying tips the first factor against the copier ...." Id. at 924. In essence, Texaco's system served to create several hundred mini-libraries of articles of interest to the 400-500 individual scientists. It distributed the work to the scientists. Futher, the system served a directly commercial purpose of taking advantage of Texaco's sheer size to pay less per scientist in the copyright market. By comparison, fifty smaller firms, with 10 research scientists each, would each have to order the entire set of journals in order to keep current in the field.

91. 510 U.S. 569 (1994).

92. See id at 572-73.

93. See id. at 579 .

94. Id.

95. Id.

96. Id.

97. Id. at 583.

98. See infra Part MI.C. for further discussion of this motivation. 
Court held that the use of material from Orbison's original might indeed be protected as a fair use, even though the copying was obvious and for commercial gain.9

The Supreme Court did not create new law with this analysis; rather, it reaffirmed the importance of transformation and provided a stronger point of departure for lower courts. ${ }^{100}$ In the wake of Campbell, lower courts have, in fact, relied heavily on the presence of transformative value to grant fair use. ${ }^{101}$ Furthermore, those cases that deny fair use properly stress that there is little transformative value in the particular use at issue. ${ }^{.02}$

\section{Potential Internalization of Any Benefits}

While distributive and transformative works may create benefits to those not at the bargaining table, these effects are only externalities that

99. See Campbell, 510 U.S. at 590-94. The Court held that the parodic character of the use was protected. However, the Court remanded the case for the lower courts to examine the effect on the potential market for rap derivatives of the song. 2 Live Crew could not have a fair use to usurp that market.

100. The Court was responding, in part, to requests for stronger guidance. See Leval, supra note 12. Judge Leval, then a district court judge, had expressed his dissatisfaction with the state of the law and with the confusing standards with which lower court judges had to work. Among other things, Leval urged the Supreme Court to assign a stronger presumption of fair use to transformative works. The Court acknowledged his article at several points in the Campbell decision.

101. For instance, a district court recently ruled that a parody can receive a fair use even if it appears in the form of an advertisement. Leibowitz v. Paramount Pictures Corp., 948 F. Supp. 1214 (S.D.N.Y. 1996). The case involved a parody of the famous photograph of a nude and pregnant Demi Moore that appeared on the cover of the August 1991 issue ofVanity Fair magazine. Paramount Pictures created a photo of a pregnant woman's body in a similar pose with Leslie Nielson's head superimposed onto the body. Paramount used the photo to advertise its upcoming movie, NAKED GUN 33 1/3: The Final Insult. Notwithstanding the fact that this was an advertisement, the court justified a fair use "by returning to the core purpose of copyright: to foster the creation and dissemination of the greatest number of creative works." Id. at 1223. The court had found this purpose would be "best served by a finding that the highly transformative cbaracter of the Nielson ad trumps its admittedly commercial purpose."Id. Later the court explained:

Three of the four fair use factors in the present case militate in favor of a finding of fair use, largely because the defendant's transformation of the plaintiff's photograph has resulted in public access to two distinct works, serving distinct markets, with little risk that the creator of the first work will be disinclined to create further works that may be open to parody."

Id. at 1226 .

102. For instance, when the Sixth Circuit denied a fair use in Michigan Document Services, it stated that "the degree to which the challenged use has transformed the original copyrighted works ... is virtually indiscemible." Princeton Univ. Press v. Michigan Document Servs., 99 F.3d 1381, 1389 (6th Cir. 1996), cert. denied, 117 S. Ct. 1336 (1997). The court concluded that the copying bore "little resemblance to the creative metamorphosis accomplished by the parodists in the Campbell case." Id.; see also Los Angeles News Service v. KCAL-TV Channel 9, 108 F.3d 1119 (9th Cir. 1997). The court denied a fair use to one television channel to broadcast another channel's tape of the Reginald Denny beating, when the user did not edit or transform the tape in any way, except to place its own call letters over the others. Even though this was a news broadcast, the complete lack of transformation weighed against fair use. See id. at 1122. This use was essentially a commercial distributive nse. 
interfere with the market if the bargaining parties cannot internalize them. When the content user sells a new work incorporating the original, she may successfully internalize the effects. This analysis should work differently depending on whether the use is distributive or transformative, but the question is relevant to either type.

In fact, the copyright system includes this inquiry in several ways. As noted above, Section 107 includes this issue in its formulation. The first subsection mandates consideration of "the purpose and character of the use, including whether such use is of a commercial nature or is for nonprofit educational purposes."103 The fourth factor also points to this type of inquiry. A court is to examine "the effect of the use upon the potential market for or value of the copyrighted work."104 Furthermore, the Supreme Court in Sony Corporation of America v. Universal City Studios, Inc. indicated that the degree of commerciality of a given use may create a presumption that a given use is or is not a fair use. ${ }^{105}$ Even though the Court subsequently cautioned that one should not elevate the presumption to a per se rule, it explained that the factor was one of many to consider. ${ }^{106}$ In accord with this idea, in both American Geophysical Union and Michigan Document Services, the courts relied on the commerciality of the use to deny fair-use protection. ${ }^{107}$

\section{Limiting American Geophysical Union and Michigan Document Services: Incorporating the Distinctions Outlined Above}

Copyright owners argue that the presence of digital networks should change the calculus, just as similar efficiency advances have in other contexts. After all, as discussed above, the courts in American Geophysical Union and Michigan Document Services disallowed copying activities that would have been fair use twenty years ago. Notwithstanding those cases, however, a court should distinguish between

103. 17 U.S.C. § 107(1) (1995).

104. 17 U.S.C. § 107(4) (1995).

105. See Sony Corp. of America v. Universal City Studios, Inc., 464 U.S. 417, 448-49 (1984) ("Although not conclusive, the first factor requires that 'the commercial or nonprofit character of an activity' be weighed in any fair use decision. If the Betamax were used to make copies for a commercial or profit-making purpose, such use would presumptively be unfair. The contrary presumption is appropriate here, however because [this was] a noncommercial, nonprofit activity." (citations omitted)).

106. See Campbell v. Acuff-Rose Music, Inc., 510 U.S. 569, 585 (1994).

107. See Princeton Univ. Press v. Michigan Document Servs., 99 F.3d I381, 1386 (6th Cir. 1996), cert. denied, 117 S. Ct. 1336 (1997) ("What the publishers are challenging is the duplication of copyrighted materials for sale by a for-profit corporation that has decided to maximize its profitsand give itself a competitive advantage over other copyshops-by declining to pay the royalties requested by the holders of the copyrigbts."); American Geophysical Union v. Texaco Inc., 60 F.3d 913, 915 (2d. Cir. 1995) ("Texaco conducts considerable scientific research seeking to develop new products and technology primarily to improve its commercial performance im the petroleum industry."). 
distributive and transformative uses and between potentially commercial and non-commercial uses before considering the effect of a seemingly more efficient market. A court should grant much more leeway to transformative uses than to purely distributive uses.

If the use is distributive, then the court should more rigidly apply the presumption that a commercial use is not a fair use. The secondcomer generates externalities that serve the public access part of the copyright balance. However, the expressive value is still entirely attributable to the original writer. If the second-comer can internalize the benefits, then he should share those with the author, in order to maintain the overall incentive strncture. Furthermore, if the second-comer distributes an exact copy of the original, we can presume that the distribution will adversely affect the market for the original and hence run afoul of Section 107(4).

On the other hand, if the use is highly transformative, then the user's ability to interualize the benefits is less important to the analysis. ${ }^{108}$ If the user generates the positive externalities through her own creation of expressive content, then copyright policy is served when that party exploits her new content. For this purpose at least, in measuring the extent of the benefits generated, it makes no defensible difference whether the party acts for profit or for other motivation. Further, she is less likely to usurp the original owner's market, because she does not merely duplicate sales the original owner could have made.

We should hesitate to extend the rationale of American Geophysical Union and Michigan Document Services to all instances of copying in digital markets. As discussed above, the defendants in both cases engaged in arguably distributive copying activity. ${ }^{109}$ Further, both cases involved highly commercial uses. ${ }^{110}$ Under the theory expounded here, both cases fall into the type least deserving of fair-use treatment.

\section{The Externality Analysis for Digital Fragmented Copies}

Fragmented copies used in secondary works are almost inherently transformative. For instance, a quote from a literary work has different expressive value when it sits in a critique than it had in its original form. Further, the entire basis of the satire or parody form is to pull the fragmentary elements of the original and to give them a different spin. But even a seemingly distributive use such as Irene's tends to gain transformative value when it is a fragment, because expression has little

108. See Campbell v. Acuff-Rose Music, Inc., 510 U.S. 569, 579 (1994) ("[T]he more transformative the new work, the less will be the significance of other factors, like commercialism, that may weigh against a finding of fair use.").

109. See supra Part 1II.B.1.

110. See supra note 107 and accompanying text. 
meaning outside of the context in which it is presented. Furthermore, the shorter the quote, the greater the effect context will have on its meaning. In Michigan Document Services, the Sixth Circuit noted that "[i]f you make verbatim copies of 95 pages of a 316 page book, you have not transformed the 95 pages very much-even if you juxtapose them to excerpts from other works." "Int Interestingly, the court focused on the fact that the context of the quoted work hardly changed at all. Conversely, it is truly difficult not to transform a short fragment. The user's discretion in selecting the fragment to copy injects some degree of expression. For example, imagine Irene picks a different quote from a novel every day and writes it on the blackboard at school. Even though she has not commented on the quote, and even if she does not tie it in with other parts of her lesson, she has changed the expressive content. She has decontextualized it from the setting it occupied in the novel. Further, she has recontextualized it on a blackboard as a group of words that this teacher obviously believes will inspire a group of a sixthgrade students. The viewers can compare and contrast this quote to others they have seen in the same setting. Though it is possible for a short quote to have little transformative value, ${ }^{112}$ most fragmented copies will present good cases for an externality analysis. ${ }^{113}$

Recognizing the value of such uses, courts examining fragmented copying in the print world have considered the commerciality of a given use, but they have set the required degree of commercialization fairly high. Most of the cases that deny fair use involve advertising activity, while other uses, even if incorporated into works for sale, receive fairuse treatment. This disparate approach probably results from the fact that advertising uses are more commercial, and entitled to less deference, than other profit-making uses. ${ }^{114}$

111. 99 F.3d at 1389. Though the copy shop did not copy the entire book, this copy was substantially longer than the truly fragmented copies that are the subject of this Comment.

112. See Dawn Assocs. v. Links, 203 U.S.P.Q. 831, 833 (N.D. Ill. 1978) (finding the defendant used the same sentence in exactly the same way to advertise a similar movie).

113. The importance of context was central to the court's reasoning in Wojnarowicz v. American Family Ass'n, 745 F. Supp. 130 (S.D.N.Y. 1990). Wojnarowicz, an artist who sought to draw attention to the AIDS crisis, worked primarily through collages. Defendants took portions of a collage to use in pamphlets designed to protest public funding of plaintiff's work. Though it was not a fair-use case, the court cited the tremendous transformative power of context:

By excising and reproducing only small portious of plaintiff's work, defendants have largely reduced plaintiff's multi-imaged works of art to solely sexual images, devoid of any pohitical and artistic content. Extracting fragmentary images from complex, multi-imaged collages clearly alters and modifies such work. Id at 138.

114. The Supreme Court has explaimed that "[t]hc use ... of a copyrighted work to advertise a product, even in a parody, will be entitled to less indulgence ... than the sale of a parody for its own sake." Campbell v. Acuff-Rose Music, Inc., 510 U.S. 569, 585 (1994). 
One typical advertising case, Dawn Associates v. Links, ${ }^{115}$ denied fair use to a phrase used in advertising a movie. The plaintiff, Dawn Associates, owned a copyright on materials for the movie Dawn of the Dead. ${ }^{116}$ The screenplay and the advertising materials for the movie included the phrase "When there is no room in hell ... the dead will walk the earth."117 The defendant, Links, appropriated this phrase to advertise its film, Return of the Living Dead. ${ }^{118}$ Links thus used the phrase in exactly the same way that Dawn Associates had. The court held that copying this one phrase was likely "such a 'substantial taking' so as to constitute infringement." 119 Other courts have reached similar conclusions when the secondary use was an advertisement. ${ }^{120}$

In contrast to the preference against use in advertising, courts tend to find fragmented quotes copied in connection with scholarly or literary work, or for use in commercial, yet non-advertising situations, to be insubstantial. For instance, the plaintiff in Toulmin v. Rike-Kulmer Co., ${ }^{121}$ wrote a 142-page historical factual account of General John J. Pershing's 1916 Punitive Expedition against Pancho Villa in Mexico. ${ }^{122}$ Twenty-three years later, Dr. Glendon Swarthout wrote a story about the event. In the foreword, Swarthout explained that the book was fictionalized. "It is a book about certain minor fictitious events before and after the lost, last charge at Ojes Azules ...."123 In the context of this fictional story, Swarthout copied without permission two sentences from Toulmin's book. The sentences concerned a cavalry officer's memories

115. 203 U.S.P.Q. 831 (N.D. Ill. 1978).

116. See id. at 833 .

117. Id.

118. See id. The film was originally entitled Messiah of Evil.

119. Id. at 835.

120. In Henry Holt \& Co., Inc. v. Liggett \& Myers Tobacco Co., 23 F. Supp. 302, 303 (E.D. Penn. 1938), Leon Felderman, an oto-larynologist (ear, nose, and throat doctor) had written a book entitled The Human Voice, Its Care and Development. See id. at 303. Defendant, a large tobacco company, produced a pamphlet for advertising purposes entitled Some Facts about Cigarettes. Under the heading "Do cigarettes affect the throat?" Ligget printed the following:

Dr. Leon Felderman, noted oto-larynologist, Philadelphia, is quoted (1931) as follows:

'Statisties have it that 80 per cent of physicians are smokers * * It appears unanimous that smoking is not nearly so injurious as over-eating *** From my experience with ear, nose and throat cases, I firmly believe that tobacco, when properly used, has no ill effect upon the auditory passages.'

Id. The court found that the material quoted was not "so unsubstantial as to be de minimis." Id. at 304. The court focused on the advertising nature of the use: "[I]t is clear that [Defendant's] pamphlet intended to advance the sale of its product-Chesterfield cigarettes-a purely commercial purpose." Id.; see also Amana Refrigeration, Inc. v. Consumers Union, Inc., 431 F. Supp. 324 (N.D. Iowa 1977) (finding that Amana's brochure, which copied a three-sentence paragraph from a Consumer Reports article, infriuged that article).

121. 137 U.S.P.Q. 533 (S.D. Ohio 1962).

122. See id. at 533.

123. Id. at $\mathbf{5 3 4}$ (quoting the book's Foreword). 
years after the events in question. ${ }^{124}$ The court found that this twosentence quotation did not infringe impermissibly Toulmin's work. The defendant wrote a novel that made use of Toulmin's factual historical account. The defendant may have taken the sentences, but he used them to enlighten a story line he invented. This transformative use ensured that the defendant's work did not "supersede the objects of the original work." 125 Again, other cases tend to fit into this pattern. ${ }^{126}$

Digital fragmented copies will largely fall outside a properly curtailed reading of American Geophysical Union and Michigan Document Services. As noted above, fragmented copies tend to be highly transformative. These transformative uses generate benefits of an entirely different character from those present in the two photocopying cases. Consequently, in most instances, fragments will present the best-case scenario for fair use. Furthermore, even purely distributive fragmented copies may qualify for fair use unless they are commercial uses.

\section{Anti-Dissemination Motives ${ }^{127}$}

Anti-dissemination motives will provide a third source of market failure in the market for digital fragments. In certain cases, an owner will refuse to license a given use at a certain price for reasons that have nothing to do with the author's attempt to gain payment for her original creation of the work. Rather, she simply may not approve of the context in which the user places the original. The content owner might object because the user writes a critical review, because the user parodies the original, ${ }^{128}$ because the author feels that the user recontextualizes the original in an offensive way, ${ }^{129}$ or because the author simply does not like the user or the user's message. ${ }^{130}$ Although anti-dissemination

124. See id.

125. Id.

126. See, e.g., Werlin v. Reader's Digest Ass'n, Inc., 528 F. Supp. 451, 464 (S.D.N.Y. 1981). Both the original content-owner and the user wrote magazine features examining the process of growing up with Downs Syndrome. The defendant copied two phrases describing the bas mitzvah celebration of Rina Cahana (a child who suffered from Downs Syndrome). The court found this copying insubstantial. See id. at 464; see also Elsmere Music, Inc. v. NBC, 482 F. Supp. 741, 744 (S.D.N.Y. 1980) (finding copying of four notes for use in a new song to be fair use).

127. The argument for fair use in this type of situation is bound up with free speech ideals. See supra note 11 and accompanying text. However, the necessity of fair use is apparent even when speaking solely in economic terms.

128. See, e.g., Campbell, 510 U.S. 569. See supra notes $88-95$ and accompanying text for further discussion of this case.

129. See, e.g., Dr. Seuss Enterprises v. Penguin Books USA, Inc., 109 F.3d 1394 (9th Cir. 1997). Dr. Seuss objected to defendant's use of elements of The Cat in the Hat in a satire, The Cat Not in the Hat, the subject of which was the O.J. Simpson trial. The satire included such quips as: "One Knife? / Two Knife? / Red Wife / Dead Wife." Id. at 1401.

130. A friend of mine recently ran into this particular problem: My friend wanted to use a short poem written by a famous deceased author. However, my friend's scholarly book targeted a gay and 
motives are by no means limited to fragmented copying, they often involve fragments. For instance, critical reviews generally use snippets of the work in order to critique. Furthermore, as discussed above, authors often use fragments in order to recontextualize the original. It is often this recontextualization that upsets the content owner.

Anti-dissemination motives stand at odds with copyright policy. As discussed above, we have designed the copyright marketplace to allow the creator to underwrite adequately the production of the content in question, not to censor downstream uses. ${ }^{131}$ The following hypothetical, based very loosely on the Campbell case, ${ }^{132}$ illustrates the manner in which anti-dissemination motives constitute a form of market failure: A musical group wants to make a parody of an older song. The band is willing to pay a fee to the songwriter for this use. The quote is worth $\$ 10,000$ to the band due to projected increased sales of the album. Suppose the songwriter will generally license this type of use for $\$ 4,000$. In the normal course, then, the transfer would go through, and the band would get a $\$ 6,000$ surplus minus whatever other transaction costs occurred (telephone calls, lawyers, etc.). Imagine the songwriter does not like the idea of a parody, but $\$ 30,000$ would offset the pain to him if the song made it to the public. Now the band would have to pay $\$ 34,000$ for the use $(\$ 4,000$ for the royalty fee and $\$ 30,000$ to overcome the songwriter's distaste for the project). That $\$ 30,000$ is essentially a transaction cost to implementation of the copyright marketplace goal (the usual reward for the original and production of this new creative work). If, as in this case, the use is only worth $\$ 10,000$ to the band, the use will not go through, and copyright goals suffer. Consequently, the band should receive fair-use treatment here. ${ }^{133}$

Interestingly, though it used different terminology, the Supreme Court in Campbell crafted essentially the solution this model would suggest. The Court did not rule that all parody merits free use. Rather, it held that the parodic character yielded a presumption that a certain degree of appropriation was acceptable. ${ }^{134}$ The Court explained that the

lesbian audience. The publisher balked at licensing this use, apparently because it feared that the use would call attention to this author's same-sex-oriented poetry.

131. See supra Part I.

132. See supra notes $92-100$ and accompanying text.

133. Judge Leval suggested an alternate solution to this problem that I believe is quite sensible and perhaps optimal. Leval proposed switching to a damages-based remedy. See Leval, supra note 12, at 1132-34. In other words, the content creator cannot enjoin the use, but she can get damages after the fact (much like a compulsory license). This solution would allow the subsequent use to go forward, while ensuring that the original content creator receives some compensation. In the terminology of this paper, the solution would eliminate the possibihity of this type of transaction cost preventing the use, while ensuring the efficient price for transfer nonetheless. Note that this idea is still quite alive. The Supreme Court urged lower courts to keep this idea in mind as they try to sift through fair-use cases. See Campbell, 510 U.S. at 578 n.10.

134. Campbell, 510 U.S. at 581. 
content owner could protect its typical markets for license of the work. Acuff-Rose could enjoin 2 Live Crew if the band infringed on the market for rap-based derivatives of "Oh, Pretty Woman!" Likewise, the songwriter in our example could always protect the $\$ 4,000$ market for typical licenses. However, Acuff-Rose could not protect the market for which it was unlikely to grant licenses, i.e., fully transformative parodies. Analogously, the songwriter in our example could not protect the inherently flawed market that led to a $\$ 30,000$ increase in price.

The Task Force's assumption that any ability to license will increase efficiency ignores the complications that arise when a copyright owner wants to suppress certain uses. Congress has chosen to give creators a monopoly as part of a larger bargain to help create more expressive works. When the copyright owner attempts to control downstream uses, she wields her monopoly power to achieve effects other than those for which Congress granted it. As a policy matter, if an author wants to take advantage of the copyright bargain, she should use her monopoly only in the quest to maximize societal interaction with her expressive work. ${ }^{135}$ An unfettered ability to demand a license fee destroys this particular balance.

The Task Force and other policy-makers should not allow content owners to import anti-dissemination motives into the digital environment. The digital market does nothing to offset the imperfections these motives generate. The increased efficiency of that market simply cannot force content owners to bargain only in the best interest of overall copyright policy. Anti-dissemination values, of course, have no more place on-line than they have in the print world. Further, as discussed above, the digital environment allows novel creative uses of fragmented copies that were impossible or unlikely before. Any digital fragmented

135. Perhaps an analogy to property theory would be appropriate here. Some theorists have described property rights as being similar to sticks in a bundle. See, e.g., JEREMY IVALDRON, THE RIGHT To PrIvate Property (1988). A land "owner" has certain rights ("sticks") that come with being an owner. He may build on the land, he may live there, or he can mortgage it to secure a loan. But he does not control all the sticks. Rather, they are reserved for society. For instance, he may not use his land in a way that creates nuisances to his neighbors, and he may not erect an unsound structure. He can sell all of these sticks he does control to another person, or he can sell some of them, but he may not bundle the sticks he does not have into a sale of the property.

The House Report on the Copyright Act explained a similar phenomenon in the different area of copyright law. In some cases, copying by a non-profit organization might be fair use. However, "[i]t would not be possible for a non-profit institution, by means of contractual arrangements with a commercial copying enterprise, to authorize the enterprise to carry out copying and distribution functions that would be exempt if conducted by the non-profit institution itself." H.R. REP. No 941476 , at 74 (1976).

A copyright owner does not have the right to prevent dissemination of her work or to control the use to which others put it. Consequently, she should not import those concerns into a bargain with the result of driving up the price or preventing a transfer altogether. If she does, a court should allow a fair use so as not to stifle the dissemination and productive use of prior works. 
copying that faces anti-dissemination motives will be a good candidate for fair use.

\section{CONCLUSION}

The White Paper proclaims, "With no more than minor clarification and limited amendment, the Copyright Act will provide the necessary balance of protection of rights-and limitations on those rights-to promote the progress of science and the useful arts."136 Further, it states that "[e]xisting copyright law needs only the fine tuning that technological advances necessitate, in order to maintain the balance of the law in the face of onrushing technology." 137 The Task Force may be right in that conclusion. However, the Task Force is misguided in its vision of how to apply the existing copyright laws to copying activity in the context of that onrushing technology. If copyright law is indeed to maintain the necessary balance, the courts and policy-makers must look beyond the copyright owner's perspective. If courts apply the analysis as the Task Force and others have recommended, they will find an absence of market failure when the market is in fact flawed. As a result, the ability of copyright owners to control content will increase dramatically without any parallel increase in the ability of society to access those works.

Of course, even commentators with a maximalist vision do not usually argue that fair use is completely without merit in a smoothly functioning digital market. Professor Goldstein and others rightly indicate that, even in this new environment, Congress may want to provide free uses to certain users for purely distributional reasons. ${ }^{138}$ Because certain uses can be valuable, Congress may simply want to underwrite them to encourage more such uses. Congress would thus direct that we should sacrifice content owners' incentives in order to subsidize certain users. I have no quibble with the idea that we may want to make such distributional decisions. The mistake is to limit the analysis to distributional concerns.

As I have argued above, the Internet will help to eliminate many market failures and thus will eliminate the need for fair use in inany cases. Nonetheless, participants in the digital market will continue to face intractable failure in many instances. This fact should not be a surprise in light of the dictates of the Copyright Act itself. It is no accident

136. White Paper, supra note 5, at 17.

137. Id.

138. See GolDSTEIN, supra note 4, at 224-25 (acknowledging that fair use might still be needed "because certain uses and users serve socially valuable ends"); Merges, supra note 8, at 134 (explaining that fair use will still be viable for certain uses where it makes sense "to do an 'end run' around the market"). 
that the list of favored uses in Section $107^{139}$ correlates directly with those types of uses that encounter externalities and anti-dissemination motives. Criticism, comment, news reporting, teaching, scholarship, and research are all uses that in the aggregate produce great benefit to society. To varying extents, these types of uses present situations in which it may be hard to internalize all of the benefit. Furthermore, criticism, comment, and news reporting all present situations in which the user is likely to face anti-dissemination motives. Congress intentionally left this list indetermmate, indicating that fair use would attain "for purposes such as" those listed above. ${ }^{140}$

To make fair use rest on distributional concerns alone is to limit the question to a policy decision. The practical effect is to confine fair use to narrow categories that a policy-making body specifically enumerates. A wise policy-making body would certainly decide to subsidize certain uses even when there is no market failure. Nonetheless, externalities, anti-dissemination motives, and even bargaining costs do not affect only easily defined classes of users, especially in the context of fragmented copies. Where these failures exist, the user will need a fair use even in the absence of a distributional policy determination covering that particular activity.

The Supreme Court has explained that the fair-use doctrine provides a "guarantee of breathing space within the confines of copyright."141 To ensure a pocket of fresh air within the digital market, policy-makers should take care not to accept suggestions, or even market conditions, that would imperil the ability to preserve some types of free public access to expressive works. Further, courts should be careful to avoid the facile assumption that every licensing market that develops is free of market failure.

Fragmented literal copying is now, and will continue to be, an excellent candidate for fair use treatment. The bargaining costs, externalities and anti-dissemination motives that remain in the digital environment will continue to affect fragmented copying. The digital environment provides a platform for more and more creative use of highly transformative fragments. We should not allow content owners to use their new-found technological tools to stifle new expression, whether in pursuit of greater income or any other goal.

139. See 17 U.S.C. § 107 (1994).

140. Id.

141. CampbelI v. Acuff-Rose Music, Inc., 510 U.S. 569, 579 (1994). 
CALIFORNIA LAW REVIEW 